\title{
Amended Consumer Bankruptcy Law in Poland
}

\section{Rafał Adamus}

\begin{abstract}
In the presented paper, the author very deeply and thoroughly explains the issue of the currently amended consumer bankruptcy law in Poland. The paper consists of four key parts. In the first part of the paper, the author clarifies the Polish legislation concerning the consumer bankruptcy; in the second part of his paper he analyses the modes of a debt relief for an insolvent natural person through the consumer bankruptcy and consumer arrangement; the third part of the paper deals with the question of the legal character of a consumer debt relief and, finally, in the last part of his paper, the author focuses on the issues of a payment morality of the debtor and its legal importance. The main summaries and key recommendations the author attaches at the end of his paper.
\end{abstract}

Key Words: Bankruptcy Law; Bankruptcy Law Act; Consumer; Consumer Bankruptcy; Insolvency; Debt Relief; Payment Morality; Poland.

\section{Introduction}

Consumer bankruptcy has been functioning in the Polish legal system since year 2008. ${ }^{1}$ The serious amendment to the provisions on consumer bankruptcy made by the Act of August 30, 2019, amending the Bankruptcy Law Act and some other acts (Journal of Laws 2019, item 1802) will certainly have a significant impact on the remarkable increase in the number of bankruptcy cases.

\section{Polish legislation concerning the consumer bankruptcy}

The history of the contemporary Polish legislation begins when Poland regains independence on November $11,1918 .^{2}$ During the partition of

1 See ADAMUS, R. Bankruptcy and Restructuring Law in Poland. Societas et iurisprudentia [online]. 2019, vol. 7, no. 2, pp. 19-49 [cit. 2019-11-04]. ISSN 1339-5467. Available at: http://sei.iuridica.truni.sk/archive/2019/02/SEI-2019-02-Studies-Adamus-Rafal.pdf; and ADAMUS, R. Consumer Bankruptcy in Poland. International and Comparative Law Review [online]. 2011, vol. 11, no. 2, pp. 93-107 [cit. 2019-11-04]. ISSN 2464-6601. Available at: https://doi.org/10.1515/iclr-2016-0106.

2 See NAMITKIEWICZ, J. Podręcznik prawa handlowego, wekslowego, czekowego i upadłościowego. 3. wyd. Warszawa: F. Hoesick, 1927, pp. 529-530; SIEDLECKI, W. Międzynarodo- 
Poland, several legal orders were in force in the field of bankruptcy: the Prussian, Austrian, Russian and French in the area of the former Congressional Kingdom ("inheritance" after the Duchy of Warsaw). In addition, the Hungarian law was in force in a small area of Spisz and Orava. Unification of the bankruptcy law in Poland of year 1934 grew out of a peculiar legal melting pot in which the German, Austrian, French and Russian influences were mixed. Foreign legal regulations did not lose their binding force in year 1918, but for a relatively long time they were the source of bankruptcy law in Poland.

Unified provisions of the Bankruptcy Law Act of October 24, 1934, predicted the bankruptcy only of "traders" by resigning from the concept of general and civil bankruptcy. As noted in the draft of the above-stated Act, the acceptance of bankruptcy only for traders was to be new, except in the area of the former Congressional Kingdom. The concept of traders (merchants) for whom bankruptcy regulation was prepared was very broadly defined.

Consumer bankruptcy was not introduced by the Act of February 28, 2003, on Bankruptcy and Reorganization $\mathrm{Law}^{3}$ (hereinafter referred to as the "Bankruptcy Law Act") which was a great reform of the insolvency law in Poland. Nevertheless, the mentioned Act for the first time allowed the possibility of a debt relief for a natural person who was an entrepreneur. ${ }^{4}$

we prawo upadłościowe. Przegląd Prawa i Administracji. 1937, nr 62, p. 7. ISSN 01371134; ALTMAN, D. Prawo upadłościowe: Komentarz. 1. wyd. Warszawa: Księgarnia Powszechna, 1936, p. 2; and ADAMUS, R. Zarys historii źródeł prawa upadłościowego w Polsce. Jurysta. 2009, nr 7, pp. 25-30. ISSN 1230-7114.

3 See Bankruptcy and Reorganization Law Act of 28 $8^{\text {th }}$ February 2003, as amended.

4 See SZPRINGER, W. Upadłość konsumencka: Inspiracje z rozwiązań światowych oraz rekomendacje dla Polski. 1. wyd. Warszawa: CeDeWu, 2006, p. 22. ISBN 978-83-60089-25-5; SZPRINGER, W. Społeczna odpowiedzialność banków: Między ochrona konsumenta a osłonq socjalnq. 1. wyd. Warszawa: Wolters Kluwer, 2009, p. 262. ISBN 978-83-7601-763-1; RUTKOWSKA, M. Upadłość konsumencka - przegląd regulacji wybranych systemów prawnych. Bank i Kredyt. 2004, vol. 35, nr 11-12, pp. 58-73. ISSN 0137-5520; LEWANDOWSKI, R., G. TARKOTTA and P. WOŁOWSKI. Projekt ustawy o przeciwdziałaniu niewypłacalności oraz o upadłości osoby fizycznej na tle niemieckiej regulacji upadłości konsumenckiej - uwagi de lege lata i de lege ferenda. Rejent. 2008, vol. 18, nr 1, pp. 99-116. ISSN 1230-669X; HANSHEW, M. Upadłość konsumencka w Niemczech. In: R. BALICKI, ed. Pro Publico Bono: Zeszyt 1. 1. wyd. Wrocław: Wydawnictwo Uniwersytetu Wrocławskiego, 2005, pp. 129-139. ISBN 978-83-229-2678-9; MICHALAK, K. Przesłanki wszczęcia konsumenckiego postępowania niewypłacalnościowego (surendettement personel) i postępowania prowadzącego do uwolnienia z reszty długów (retablissement personel) we Francji. Transformacje Prawa Prywatnego. 2008, nr 1, pp. 33-56. ISSN 1641-1609; MICHALAK, 
On December 5, 2008, the Polish Parliament finally adopted the Act amending the Bankruptcy and Reorganization Law Act. ${ }^{5}$ The subject of

K. Przebieg konsumenckiego postępowania niewypłacalnościowego (surendettement personel) i postępowania prowadzącego do uwolnienia osoby fizycznej z reszty długów (retablissement personel) we Francji. Transformacje Prawa Prywatnego. 2008, nr 2, pp. 49-75. ISSN 1641-1609; and KABZA, E. Upadłość konsumencka w USA. Przegląd Prawa Egzekucyjnego. 2010, nr 5, pp. 79-110. ISSN 1731-030X.

5 See TERESZKIEWICZ, P. Postępowania upadłosciowe i oddłużeniowe dla konsumentów w Stanach Zjednoczonych i w niektórych krajach europejskich: Część 1. Transformacje Prawa Prywatnego. 2000, nr 1-2, pp. 99-122. ISSN 1641-1609; TERESZKIEWICZ, P. Postępowania upadłościowe i oddłużeniowe dla konsumentów w Stanach Zjednoczonych i w niektórych krajach europejskich: Część 2. Transformacje Prawa Prywatnego. 2000, nr 3, pp. 27-57. ISSN 1641-1609; SZPRINGER, W. Kredyt konsumencki i upadłość konsumencka na rynku usług finansowych UE. 1. wyd. Warszawa: Dom Wydawniczy ABC, 2005, pp. 74-76. ISBN 83-7416-235-X; GURGUL, S. Postępowanie upadłościowe wobec osób fizycznych nieprowadzących działalności gospodarczej: Część 1. Monitor Prawniczy. 2009, vol. 17, nr 10, pp. 527-537. ISSN 1230-6509; GURGUL, S. Postępowanie upadłościowe wobec osób fizycznych nieprowadzących działalności gospodarczej: Część 2. Monitor Prawniczy. 2009, vol. 17, nr 11, pp. 592-601. ISSN 1230-6509; ZALEWSKI, C. Nowelizacja prawa upadłościowego i naprawczego. Przegląd Prawa Handlowego. 2009, nr 5, pp. 4-7. ISSN 1230-2996; ADAMUS, R., A. J. WITOSZ and A. WITOSZ. Upadłość konsumencka: Komentarz praktyczny. 1. wyd. Warszawa: LexisNexis, 2009. 102 p. ISBN 978-83-7620-118-4; ADAMUS, R. Wierzytelności banku w upadłości konsumenckiej. Jurysta. 2009, nr 3-4, pp. 4145. ISSN 1230-7114; ZIMMERMAN, P. Prawo upadłościowe i naprawcze: Komentarz. 2. wyd. Warszawa: C. H. Beck, 2012, p. 981. ISBN 978-83-255-3091-4; WITOSZ, A. J. Plan spłaty wierzycieli w upadłości konsumenckiej. Monitor Prawniczy. 2010, vol. 18, nr 10, pp. 584-592. ISSN 1230-6509; MICHALAK, K. Ogłoszenie upadłości osób fizycznych nieprowadzących działalności gospodarczej na podstawie znowelizowanej ustawy Prawo upadłościowe i naprawcze. Transformacje Prawa Prywatnego. 2009, nr 3-4, pp. 67-88. ISSN 1641-1609; WITOSZ, A. Przekształcenie jednoosobowego przedsiębiorcy w jednoosobową spółkę kapitałową a problem zdolności upadłościowej. Przegląd Prawa Handlowego. 2013, nr 4, pp. 4-7. ISSN 1230-2996; WITOSZ, A. J. Likwidacja własna masy upadłości przez konsumenta. Monitor Prawniczy. 2009, vol. 17, nr 19, pp. 1074-1080. ISSN 12306509; WITOSZ, A. J. Skutki prawne upadłości wspólnika spółki osobowej. Przegląd Prawa Handlowego. 2014, nr 4, pp. 8-12. ISSN 1230-2996; GŁODOWSKI, W. and A. HRYCAJ. Postępowanie w przedmiocie ogłoszenia upadłości konsumenckiej. Ruch Prawniczy, Ekonomiczny i Socjologiczny. 2011, vol. 73, nr 3, pp. 113-123. ISSN 0035-9629; GŁODOWSKI, W. and A. HRYCAJ. Zakres podmiotowy i podstawy ogłoszenia „upadłości konsumenckiej”. Państwo i Prawo. 2010, vol. 65, nr 2, pp. 70-82. ISSN 0031-0980; ZACHMIELEWSKA, 0. Upadłość konsumencka w świetle domniemania racjonalności ustawodawcy. Państwo i Prawo. 2010, vol. 65, nr 11, pp. 96-107. ISSN 0031-0980; ADAMUS, R. Bank wobec upadłości konsumenckiej swojego dłużnika. Monitor Prawa Bankowego. 2011, vol. 2, nr 2, pp. 53-70. ISSN 2081-9021; ADAMUS, R. Likwidacja masy upadłości: Zagadnienia praktyczne. 1. wyd. Warszawa: Difin, 2014, p. 22. ISBN 978-83-7930-261-1; ŚWIECKA, B. ed. Bankructwa gospodarstw domowych: Perspektywa ekonomiczna i społeczna. 1. wyd. Warszawa: Difin, 2008. 320 p. ISBN 978-83-7251-918-4; FALKIEWICZ, K. and K. DOPIERAŁA. Wady ustawy o upadłości konsumenckiej. Fenix.pl. 2013, vol. 4, nr 2, pp. 22-26. ISSN 
this amendment were new, separate bankruptcy proceedings referred to as consumer bankruptcy. The Act of December 5, 2008, did not provide sufficient consumer protection. In practice, many problems resulted in the correct formulation of the bankruptcy petition due to its considerable formalism. In addition, provisions on consumer bankruptcy did not exclude the application of the Article 13 of the Bankruptcy Law Act about the need to have assets to cover the costs of the proceedings.

In the justification of the bill of December 5, 2008, there were highlighted certain trends in the European legislation in the field of consumer bankruptcy. It was noted that "no open access to bankruptcy debt is anticipated. On the contrary, accessibility is limited to those debtors who are considered worthy of such access. As a result of this approach, there is a tendency in Europe to attribute moral categories to excessive consumer indebtedness and to access to debt relief programs". ${ }^{6}$ Further, there was indicated the crucial role of mandatory debt repayment plans. "Debt relief is subject to conditions or is not granted prior to the implementation of the repayment plan, lasting five to seven years." Lastly, it was noted that "the European model places particular emphasis on debtrelated advisory services. Counselling aims to rehabilitate the debtor educate him/her economically and change his/her lifestyle as well as cause that the debt will be repaid as much as possible. Advisory services for debtors are an integral part of the debt relief procedure. The ways of implementing this assumption differ in the legislation of different European countries, but, generally speaking, debt relief laws require indebted con-

2082-3398; BUNK, A., V. LICHTER and M. R. PIETRZAK. Upadłość konsumencka w Niemczech. Fenix.pl. 2011, vol. 2, nr 4, pp. 29-34. ISSN 2082-3398; CHAJDA, M. and M. SKWARZYŃSKI. Upadłość konsumencka twórcy. In: M. ZAŁUCKI, ed. Własność intelektualna w prawie upadłościowym i naprawczym. 1. wyd. Warszawa: IUSatTAX, 2012, pp. 43-53. ISBN 978-83-62682-12-6; BABIARZ-MIKULSKA, K. Postępowanie upadłościowe wobec osób nieprowadzących działalności gospodarczej. Przegląd Prawa Handlowego. 2011, nr 12, pp. 55-58. ISSN 1230-2996; KABZA, E. Wybrane problemy upadłości konsumenckiej w świetle nowej regulacji. Studia Iuridica Toruniensia [online]. 2009, nr 5, pp. 121139 [cit. 2019-11-04]. ISSN 2391-7873. Available at: https://doi.org/10.12775/sit.2009. 007; SOKAL, P. Postępowanie upadłościowe wobec osób fizycznych nieprowadzących działalności gospodarczej. Przegląd Prawa Egzekucyjnego. 2009, nr 8, pp. 79-111. ISSN 1731-030X; JAŚLIKOWSKI, M. Podstawy ogłoszenia upadłości konsumenckiej w praktyce sądów powszechnych. Prawo w Działaniu [online]. 2011, nr 10, pp. 43-99 [cit. 2019-1104]. ISSN 2657-4691. Available at: https://iws.gov.pl/wp-content/uploads/2018/09/Marek-Ja\%C5\%9Blikowski-Podstawy-og\%C5\%82oszenia-upad\%C5\%82o\%C5\%9Bci-konsumenckiej-w-praktyce-s\%C4\%85d\%C3\%B3w-powszechnych-43.pdf; and Print No. 556 of the Sejm of the Republic of Poland of the $6^{\text {th }}$ Term.

${ }^{6}$ See Print No. 556 of the Sejm of the Republic of Poland of the $6^{\text {th }}$ Term. 
sumers to seek advice and negotiation or mediation with creditors before filing for bankruptcy or debt relief to solve the debt problem. Contrary to the legal solutions regarding consumer bankruptcy adopted in the North America, the European laws take into account moral issues when determining the availability of debt relief procedures, which is expressed by the obligatory repayment plan and advice for debtors. These provisions arise from the assumption that under the European law excessive debt is understood as a social problem and not as a market failure". ${ }^{7}$

Thus consumer bankruptcy was, regulated by the Bankruptcy and Reorganization Law Act, as separate bankruptcy proceedings to which the provisions on bankruptcy were applicable - according to the then nomenclature - involving the liquidation of the debtor's assets. The legislator rejected earlier concepts of regulating consumer bankruptcy in a separate act.

Consumer bankruptcy in its original form not only provided for the debtor's assets to be credited for the purpose of paying off creditors, but also for the write-off of the debtor's unmet obligations (Article $491^{12}$ of the amended Bankruptcy Law Act) after the implementation of the socalled repayment plan established by the court at the debtor's request, after the final division plan has been drawn up (Article $491^{7}$ of the amended Bankruptcy Law Act). The construction of the cancellation of unmet obligations under consumer bankruptcy showed some similarity to the so-called debt relief proceedings of natural persons - entrepreneurs as a part of ordinary insolvency proceedings (Articles 369 and 370 of the amended Bankruptcy Law Act). Why? Prerequisites for a debt relief under the Article 369 Section 1 point 1 of the amended Bankruptcy Law Act corresponded to the conditions of consumer bankruptcy.

As part of the bankruptcy proceedings of a natural person, the satisfaction of creditors took place by the way of distribution of mass funds or on the basis of the so-called rights of separateness. From the point of view of the interests of creditors, not only the distribution system of the assets of the bankruptcy estate to satisfy creditors' claims is important, but also the possibility of seeking satisfaction from the debtor after the end of his/her bankruptcy proceedings. Basically, the debt relief institutes close the way to seeking satisfaction after the end of insolvency proceedings.

7 See Print No. 831 of the Sejm of the Republic of Poland of the $6^{\text {th }}$ Term. 
Consumer bankruptcy was held by natural persons "to whom the provisions of the Chapter II, Title I, Part One do not apply" (Article $491^{1}$ of the amended Bankruptcy Law Act). The bankruptcy capacity of consumers was held by natural persons who: were not entrepreneurs, were not partners of commercial partnerships, were responsible for the company's obligations without limitation with all their assets, i.e. they were not partners of a general partnership and general partners in a limited partnership and limited joint-stock partnership, were not partners of the partner company. Natural persons running an agricultural farm also had consumer bankruptcy capacity.

The design of the premises for a declaration of consumer bankruptcy was complex. Firstly, the basis for the bankruptcy of a natural person was his/her insolvency within the meaning of the Article 11 Section 1 of the amended Bankruptcy Law Act in the shape of the cessation of performance of due monetary obligations. It had no direct significance for the conditions of consumer bankruptcy for the non-performance by a natural person of non-pecuniary obligations. Secondly, according to the Article $491^{3}$ Section 1 of the amended Bankruptcy Law Act, the bankruptcy court dismissed the bankruptcy petition if the debtor's insolvency was not caused by exceptional and independent circumstances. The legislator exemplified two situations in which the court obligatorily dismissed the bankruptcy petition. The first one is when the debtor made a commitment, being insolvent. The second one is when the termination of the employment relationship occurred for reasons attributable to the debtor.

The legislator's assumption at that time was a very narrow "opening" of consumer bankruptcy. In the justification of the bill, it was raised that "Article $491^{3}$ implements the basic principle applicable to consumer bankruptcy, according to which the possibility of using this procedure should be something special. Therefore, it is assumed that insolvency proceedings can only be conducted against persons who have become insolvent due to exceptional and independent circumstances beyond their control." 8 The "exceptional" circumstance meant a special situation, not universal. In turn, "independent" circumstances are circumstances not caused by the debtor himself/herself (e.g. the debtor has lost the opportunity to earn as a result of an accident or serious illness, etc.).

The legislator has not decided to introduce the principle of consumer bankruptcy only once in the life of a natural person (the principle of one

8 See Print No. 831 of the Sejm of the Republic of Poland of the $6^{\text {th }}$ Term. 
time debt relief). In a simplification, it can be stated that consumer bankruptcy could be used - no more than every 10 years.

Amended provisions on consumer bankruptcy, adopted by the Act of August 29, 2014, on the amendment to the Act on Bankruptcy and Reorganization Law, the Act on the National Court Register and the Act on Court Costs in Civil Matters differed so seriously from the previous regulation introduced by the Act of December 5, 2008 (the Act on Bankruptcy and Reorganization Law (the "Bankruptcy Law Act") in the wording of the Act of December 5, 2008, hereinafter referred to as the "Act"), that one could speak of a "new consumer bankruptcy" in Poland. 9

9 See ZIMMERMAN, P. Prawo upadłościowe i naprawcze: Komentarz. 3. wyd. Warszawa: C. H. Beck, 2015. 1232 p. ISBN 978-83-255-6878-8; FILIPIAK, P., A. HRYCAJ and Ł. LIPOWICZ. Upadłość konsumencka po dużej nowelizacji: Komentarz. 1. wyd. Poznań: Spartian, 2015. 326 p. ISBN 978-83-64651-13-7; ADAMUS, R. Nowa upadłość konsumencka: Poradnik praktyczny. 1. wyd. Warszawa: Difin, 2015. 188 p. ISBN 978-83-7930-614-5; WITOSZ, A. Układ w upadłości konsumenckiej. Przegląd Prawa Handlowego. 2015, nr 2, pp. 18-23. ISSN 1230-2996; WITOSZ, A. J. Przesłanki ogłoszenia upadłości konsumenckiej. Przegląd Prawa Handlowego. 2015, nr 2, pp. 24-32. ISSN 1230-2996; WITOSZ, A. J. Wierzyciel w upadłości konsumenckiej. In: J. OLSZEWSKI, ed. Tendencje reformatorskie $w$ prawie handlowym: między teoriq a praktykq̨. 1. wyd. Warszawa: C. H. Beck, 2015, pp. 113-124. ISBN 978-83-255-7784-1; ADAMUS, R. Nowa upadłość konsumencka. Monitor Prawa Bankowego. 2015, vol. 6, nr 2, pp. 102-111. ISSN 2081-9021; ADAMUS, R. Zaspokojenie wierzyciela rzeczowego w upadłości konsumenckiej. Przegląd Prawa Handlowego. 2015, nr 2, pp. 33-37. ISSN 1230-2996; ADAMUS, R. Upadłość osoby fizycznej nieprowadzącej działalności gospodarczej. Radca.pl. 2015, vol. 2, nr 2, p. 28. ISSN 2543-7437; PANNERT, M. Upadłość konsumencka po zmianach - problemy węzłowe. In: J. OLSZEWSKI, ed. Tendencje reformatorskie w prawie handlowym: między teoriq a praktyką. 1. wyd. Warszawa: C. H. Beck, 2015, pp. 135-143. ISBN 978-83-255-7784-1; SAGAN, B. Zmiany w regulacji upadłości konsumenckiej - wybrane zagadnienia. In: J. OLSZEWSKI, ed. Tendencje reformatorskie w prawie handlowym: między teoriq a praktykq. 1. wyd. Warszawa: C. H. Beck, 2015, pp. 145-152. ISBN 978-83-255-7784-1; HOFMAN, T. Upadłość konsumencka 2015. Monitor Prawniczy. 2015, vol. 23, nr 16, pp. 858-863. ISSN 1230-6509; WOŁOWSKI, P. Układ w upadłości konsumenckiej - wybrane zagadnienia. Rejent. 2015, vol. 25, nr 8, pp. 121-137. ISSN 1230-669X; CAŁUS, E. Upadłość konsumencka - doświadczenia i perspektywy. Przegląd Prawa i Administracji. 2015, nr 101, pp. 11-24. ISSN 0137-1134; WOŁOWSKI, P. Upadłość konsumencka na podstawie nowelizacji ustawy Prawo upadłościowe i naprawcze z dnia 29 sierpnia 2014 r. Transformacje Prawa Prywatnego. 2014, nr 4, pp. 53-68. ISSN 1641-1609; SZAFRAŃSKI, P. Uwagi do projektu zmian w prawie upadłościowym osób fizycznych nieprowadzących działalności gospodarczej, przedstawionego na konferencji Ministerstwa Sprawiedliwości oraz Ministerstwa Gospodarki w dniu 10 grudnia 2012 roku. Polski Proces Cywilny. 2013, nr 2, pp. 174-193. ISSN 2082-1743; KUGLARZ, P. Podstawowe standardy upadłości konsumenckiej w Polsce na tle wybranych regulacji europejskich. Doradca Restrukturyzacyjny. 2015, nr 1, pp. 33-43. ISSN 2450-1956; WERENGOWSKI, J. Postępowanie upadłościowe bez udziału wierzycieli. Doradca Restrukturyzacyjny. 2015, nr 1, pp. 44-50. ISSN 2450-1956; TATARA, K. and M. KALIŃSKI. Wąt- 
At the same time, the practical importance of consumer bankruptcy institutes has increased immeasurably.

According to the amended Article 2 Section 2 of the Act, the proceedings regulated by the Act against natural persons who did not conduct business activity had to be conducted in such a way as to enable the waiver of the bankrupt's obligations not performed in the bankruptcy proceedings, and if it was possible - to satisfy the claims of creditors as much as possible. In other words, the objectives of consumer bankruptcy were first formulated as follows: firstly, debt relief ("shaking off" debts); secondly, as far as possible, maximum satisfaction of creditors.

The structure of the provisions cited above showed that the objectives of consumer bankruptcy were gradual. Such insolvency proceedings were allowed in relation to natural persons who did not run a business in which there would be no satisfaction of creditors at all. As part of consumer bankruptcy, it became possible to omit: the liquidation stage of the bankruptcy estate in the absence of assets, the stage of the repayment plan in the absence of prospects for its implementation.

The primacy of the bankrupt's debt was reflected in many specific institutes of the new consumer bankruptcy. It was also an important interpretative hint when interpreting the provisions on proceedings.

Act of August 29, 2014, for the first time excluded the application of the provisions on poverty, bankruptcy estate (Article 13 of the Act). This regulation was of key importance in particular if compared to the previous legal standards. Exclusion of the application of the Article 13 of the Act to consumer bankruptcy opened the way for a debt relief for debtors who retain the so-called payment morality, but often without sufficient funds to cover the costs of proceedings.

Consumer bankruptcy shaped by the Act of August 29, 2014, despite significant liberalization of regulations (compared to the model from year 2008) and bringing them closer to the needs of debtors, was not of an "open" nature, i.e. available to every insolvent debtor. This meant that the bankruptcy court should have examined in detail the so-called pay-

pliwości odnośnie do przesłanki złożenia wniosku o ogłoszenie upadłości w terminie w przypadku menedżerów lub byłych przedsiębiorców ubiegających się o upadłość konsumencką. Doradca Restrukturyzacyjny. 2015, nr 1, pp. 81-87. ISSN 2450-1956; and JANDA, P. Czynności syndyka w postępowaniu upadłościowym prowadzonym wobec osób fizycznych nieprowadzących działalności gospodarczej w ujęciu praktycznym. Doradca Restrukturyzacyjny. 2016, nr 1, pp. 23-31. ISSN 2450-1956. 
ment morality of an insolvent debtor in proceedings in declaration of bankruptcy.

According to the regulations at that time, the institute of consumer bankruptcy (and its results: the benefits of debt relief) was not allowed for a debtor who intentionally had incurred obligations exceeding his/ her financial capacity, and then had been unable to satisfy creditors. It was then believed that a completely "open" consumer bankruptcy could promote very negative social attitudes. Limiting access to consumer bankruptcy was considered to be systemically justified because consumer bankruptcy opened the way for the debtor to completely write off his/ her liabilities which were subject to the repayment plan.

The grounds for declaring consumer bankruptcy were as follows.

Firstly, the premise for the declaration of consumer bankruptcy was the insolvency of the debtor - a natural person pursuant to the provisions of the Articles 10 and 11 Section 1 of the Act. Due to the way this premise was formulated in the Act, it could be described as a 'positive premise'. It is clear that it is not permissible to declare consumer bankruptcy against a solvent person. Indebtedness of a solvent person would lead to a completely unjustified harm to creditors and a completely unjustified privilege for the debtor without any axiological justification. Also the state of threat of insolvency (which was then the basis for initiating - currently repealed - entrepreneurial restructuring proceedings) did not justify the declaration of consumer bankruptcy. Insolvency is an objective category, not a subjective conviction of the debtor about a given state of affairs.

Secondly, the premise for the declaration of consumer bankruptcy, in accordance with the Article $491^{4}$ of the Act, was a debtor's payment morality. Due to the formulation of this premise in the Act, it could be described as a 'negative premise'.

According to the Article $491^{4}$ Section 1 of the Act, the bankruptcy court dismissed the bankruptcy petition if the debtor had become insolvent or significantly increased its degree intentionally or through gross negligence. Pursuant to the Article $491^{4}$ Section 2 of the Act, the court dismissed the bankruptcy petition if, within ten years before filing for bankruptcy,:

insolvency proceedings were conducted against the debtor pursuant to the provisions on consumer bankruptcy, if the proceedings were 
discontinued for reasons other than at the request of the debtor himself/herself; or

the creditors' repayment plan established for the debtor was repealed pursuant to the Article $491^{20}$ of the Act; or

the debtor, having such an obligation, did not file for bankruptcy within the deadline; or

the legal action of the debtor has been legally recognized as having been done to the detriment of creditors,

unless the conduct of the proceedings was justified on grounds of equity or humanitarian reasons.

In addition, the bankruptcy court dismissed the application for declaration of bankruptcy if, within a period of ten years prior to the date of filing the application, the debtor had been subject to bankruptcy proceedings in which all or part of his/her obligations had been written off, unless the debtor's insolvency or its increase occurred despite the debtor's due diligence or the conduct of the proceedings was justified on grounds of equity or humanitarian reasons (Article $491^{4}$ Section 3 of the Act).

Finally, the bankruptcy court dismissed the application for declaration of bankruptcy if the data provided by the debtor in the application were untrue or incomplete, unless the incompatibility or incompleteness was not significant or the conduct of the proceedings was justified on grounds of equity or humanitarian reasons (Article $491^{4}$ Section 3 of the Act).

As part of the premise referred to in the Article $491^{4}$ of the Act first of all, it was seriously important for what reasons the debtor was insolvent.

Both types of premises (positive from the Articles 10 and 11 Section 1 of the Act and negative from the Article $491^{4}$ of the Act) were subject to examination by the bankruptcy court at the stage of proceedings regarding the declaration of consumer bankruptcy.

Act of August 29, 2014, for the first time allowed the restructuring model of consumer bankruptcy, which was directly regulated in the content of two provisions of the Articles $491^{22}$ and $491^{23}$ of the Bankruptcy Law Act u.n. Pursuant to this synthetic regulation (if it was probable that the objectives of the bankruptcy procedure would be achieved through the arrangement - in this case: satisfaction of creditors and debt relief), 
the judge-commissioner, acting on the bankrupt's application (the legislator excluded the initiative of creditors in the scope of the application for conclusion of an arrangement), called a meeting of creditors to conclude an arrangement (the bankrupt could appealed against the decision refusing to convene a meeting of creditors).

Some changes to the provisions on consumer bankruptcy were introduced on January 1, 2016, as a consequence of a major reconstruction of the insolvency law in Poland made by the Act of May 15, 2015. There was a further increase in the number of consumer bankruptcies. ${ }^{10}$

The next milestone in the debt relief for natural persons is the Act of August 30, 2019. The date of entry into force of the core of this amendment is March 24, 2020.

The legislator's assumption is to streamline the consumer bankruptcy procedure and to make it available to even more indebted persons.

At the same time, many modes of debt relief have been allowed, which is beneficial in itself, but with rather poor legal awareness of the public it can be an untapped potential.

First of all, the most important change seems to be the abandonment of the need to examine the so-called payment morality of the debtor, including the debtor's fault in bringing or deepening insolvency by the bankruptcy court at the stage of declaring bankruptcy. The explanatory memorandum to the draft law states that the former solutions allowing dismissal of the bankruptcy petition on the basis of the finding that the debtor had no payment morality "are the reason for significant judicial differences in individual court districts, contributing to the phenomenon of 'tourism' bankruptcy in the country." 11

${ }^{10}$ See GEROMIN, M. Upadłość konsumencka w świetle zmian wprowadzonych ustawą - Prawo restrukturyzacyjne. Monitor Prawniczy. 2016, vol. 24, nr 4, pp. 177-187. ISSN 12306509; HRYCAJ, A., A. OWCZAREWICZ and A. PAWŁOWSKI. Postanowienie sądu o ustaleniu planu spłaty w postępowaniu upadłościowym prowadzonym wobec osoby fizycznej nieprowadzącej działalności gospodarczej. Doradca Restrukturyzacyjny. 2016, nr 4, p. 32. ISSN 2450-1956; MEDYŃSKI, M. and K. FORYSIAK. Status wierzyciela w postępowaniu upadłościowym osoby fizycznej nieprowadzącej działalności gospodarczej. Monitor Prawa Bankowego. 2016, vol. 7, nr 6, pp. 88-100. ISSN 2081-9021; and MEDYŃSKI, M. and K. KRAWIEC. Małżeńskie ustroje majątkowe w przypadku ogłoszenia upadłości konsumenckiej. Monitor Prawa Bankowego. 2016, vol. 7, nr 5, pp. 83-92. ISSN 2081-9021.

${ }^{11}$ See Print No. 3480 of the Sejm of the Republic of Poland of the $8^{\text {th }}$ Term. 
However, this does not mean giving up the importance of payment morality for the possibility of a debt relief for an insolvent natural person. "Any improper behaviour of the debtor [...] will be examined at the stage of determining the repayment plan of creditors and, therefore, when the behaviour of the debtor can also be heard by creditors". ${ }^{12}$

The debtor is allowed to enter into an arrangement with creditors outside the court. New separate proceedings were introduced - proceedings for the conclusion of an arrangement at a meeting of creditors by a natural person not conducting business activity.

There is a possibility to take advantage of the institute of prepared liquidation of debtor's assets (pre-pack). In accordance with the Article $491^{2}$ Section 1a of the Act, a participant in the proceedings may submit an application - before the announcement of debtor's bankruptcy for approval of the conditions of sale of assets of significant value. The provisions of the Articles 56a - 56h of the Act (designed for prepared liquidation of entrepreneur's assets) shall apply accordingly.

In order to simplify and to accelerate proceedings for consumers, appointment of a judge-commissioner in consumer bankruptcy was abandoned (to compensate for the lack of a judge-commissioner, there is a new institute of a complaint to the bankruptcy court regarding the trustee's activities - Article 4912a of the Act).

\section{Modes of the debt relief for an insolvent natural person through the consumer bankruptcy and consumer arrangement}

The entire legal structure of consumer bankruptcy is subordinated to the debt relief of an insolvent natural person. In accordance with the Article 2 Section 2 of the Act, proceedings governed by the Act on natural persons should also be conducted in such a way as to enable remission of the debtor's obligations not performed in bankruptcy proceedings.

The legislator adopted two models of the consumer debt relief due to the criterion referring to the decision factor on debt relief. The first one cancellation of obligations may take place by a court order. In this model of the debt relief, the creditors' will on whether to write off the debtor's liabilities has no causative power. The court may cancel the debtor's obligations against the will of all or most creditors. The second one - the debt relief may take place under a consumer arrangement providing for

\footnotetext{
${ }^{12}$ See Print No. 3480 of the Sejm of the Republic of Poland of the $8^{\text {th }}$ Term.
} 
the write-off of part of the obligations accepted by most creditors. The arrangement may be concluded after the declaration of bankruptcy (in separate proceedings conducted in accordance with the provisions of the Title V of Part Three of the Act or in ordinary proceedings) or - without declaring the debtor's bankruptcy - in proceedings for concluding an arrangement at a meeting of creditors (in other separate proceedings conducted in accordance with the provisions of the Title VI of Part Three of the Act). In this model of the debt relief, the court's competence is limited to adjudicating on the approval of the arrangement. The regulation on the consumer arrangement is, in fact, very residual in the provisions of the Act. The provisions of the Restructuring Law Act ${ }^{13}$ apply in all of the above-mentioned consumer arrangement modes.

The debt relief can take the form of definitive or non-definitive. The write-off of "non-definitive" obligations applies to all modes of the consumer agreement due to the possibility of repealing the agreement and the so-called conditional remission of liabilities in consumer bankruptcy.

An important feature of modern debt relief in Poland is its multiformity. The legislator presents at the disposal of an insolvent debtor a natural person who does not run a business - several modes of the debt relief.

First of all, the debtor's debts may be removed by decommitment of the bankrupt's obligations by a court order after the repayment plan has been completed in separate proceedings (or in ordinary proceedings applicable to entrepreneurs in the case referred to in the Article $491^{1} \mathrm{Sec}-$ tion 2 of the Act). It should be stressed that a repayment plan has a separate legal basis as well as a different legal significance in ordinary and separate proceedings for a debt relief.

There are significant differences between the ad quem deadline for bankruptcy proceedings in the ordinary procedure and in the separate mode. In ordinary proceedings, in accordance with the Article 368 Sections 1 and 2 of the Act, the court after completing the final division plan states the termination of the bankruptcy proceedings. The court also states the termination of the proceedings if all creditors were satisfied in the course of the proceedings. According to the Article 369 Section 1 of the Act, within thirty days of the date of the announcement of the order terminating the bankruptcy proceedings, the bankrupt who is a natural

${ }^{13}$ See Restructuring Law Act of $15^{\text {th }}$ May 2015, as amended. 
person may submit a request to establish a repayment plan for creditors and to write off the remainder of the obligations that were not met in the insolvency proceedings. On the other hand, in separate proceedings the repayment plan of the sense largo fulfils the functions of a list of claims and a division plan as well. In accordance with the Article $491^{14}$ Section 8 of the Act, a decision establishing a repayment plan for creditors or cancelling the debtor's obligations without establishing a repayment plan for creditors or conditional cancellation of the debtor's obligations without setting a creditors' repayment plan means the termination of the bankruptcy proceedings. This way of regulating the issue of termination of insolvency proceedings leads to many inconsistencies. In most cases, the debtor's debt is written off after the bankruptcy proceedings have ended.

The debt relief can take place through the write-off of the bankrupt's obligations by a court order after repealing the repayment plan which the bankrupt is unable to perform for objective reasons in separate proceedings (or in ordinary proceedings applicable to entrepreneurs in the case referred to in the Article $491^{1}$ Section 2 of the Act).

The debt relief can take place through the cancellation of the debtor's obligations by a court order without setting a repayment plan in separate proceedings (or in ordinary proceedings applicable to entrepreneurs in the case referred to in the Article $491^{1}$ Section 2 of the Act).

The debt relief may take place pursuant to the bankruptcy court's order by the way of a conditional remission of the debtor's obligations without establishing a repayment plan for creditors in separate proceedings (or in ordinary proceedings applicable to entrepreneurs in the case referred to in the Article $491^{1}$ Section 2 of the Act).

The debt relief may take place by the way of an arrangement in separate proceedings (or in ordinary proceedings applicable to entrepreneurs in the case referred to in the Article $491^{1}$ Section 2 of the Act).

The debt relief for an insolvent natural person not conducting business activity may take place in proceedings for the conclusion of an arrangement at the creditors' meeting, without declaration of consumer bankruptcy.

The cancellation of obligations applies, subject to exceptions provided for by the Act, to all obligations covered by the insolvency proceedings, regardless of their legal nature (source of origin). The cancellation of obligations in consumer bankruptcy occurs on the basis of a judgment 
of the bankruptcy court. The cancellation of obligations is compulsory, which means that it also occurs against the will of creditors, and certainly in an independent manner.

The legal effect of a final court decision on the write-off of liabilities is the loss of legal existence of the debtor's liabilities (with the "universal" meaning of the concept of liability).

\section{Legal character of the consumer debt relief}

A claim that cannot be satisfied from the debtor's assets, even under the state coercion, cannot last forever. The legal system includes provisions on the limitation of claims and the expiration of claims. The effects of limitation and expiration of claims are somewhat similar to the effects of debt relief. Debt relief does not mean consent to the non-payment of debts by the debtor who has the property or by the debtor who has hidden the property through acts detrimental to creditors. Debt relief is applied in a situation - according to theoretical assumptions - when the debtor is not able to pay debts. Debt relief allows for social and economic reactivation of the debtor with obvious social benefits.

A debt relief is voluntary by nature from the debtor's point of view. Debt relief - in relation to the debtor - is not compulsory. The debtor is only entitled to file for bankruptcy. He/she is not obliged to file for consumer bankruptcy. The provision of the Article $491^{2}$ Section B. C. of the Act excludes the regulation of the Article 21 of the Act on the obligation (statutory constraint) to file for bankruptcy. Filing of an application for consumer bankruptcy is, therefore, the debtor's right (privilege) and is entirely optional. The declaration of consumer bankruptcy causes farreaching consequences for the bankrupt (Article 57 of the Act), his/her property and the possibility of using and disposing of this property (Article 61 of the Act), matrimonial property relations (Article 124 of the Act) as well as other. The debtor is not liable for damages for failing to file for bankruptcy (Article 21 Section 3 of the Act). The debtor does not bear such responsibility towards the spouse (irrespective of the matrimonial property regime between the spouses).

The debtor may at any time - until the date of declaration of bankruptcy - withdraw the application for declaration of consumer bankruptcy. It should also be assumed that the debtor may withdraw the application also after the court rejects the application, but before it becomes final. However, pursuant to the Article 29a Section 1 of the Act which is 
applicable in separate proceedings, the bankruptcy court may declare the withdrawal of the bankruptcy petition inadmissible if it would lead to harm to creditors. In accordance with the Article $491^{10}$ Section 1 of the Act, the court discontinues the bankruptcy proceedings at the request of the bankrupt. However, the court does not discontinue the proceedings if the discontinuation of the proceedings could result in harm to creditors (Article $491^{10}$ of the Act). The debtor can influence the course of proceedings through the instrument of withdrawing the application and discontinuing the proceedings.

In accordance with the Article $491^{4}$ Section 2 of the Act, in the case of proceedings initiated solely at the request of the creditor, the trustee shall submit to the court a draft plan for the repayment of creditors with reasons or information on conditions referred to in the Article 49114a Section 1 or the Article $491^{16}$ Section 1 or 2 of the Act, unless the debtor at the call of the trustee declares that he/she does not request the preparation of a creditors' repayment plan.

There is a strong connection between the debt relief and the bankruptcy proceedings (under which apply standards adopted by the legislator to protect creditors' interests). The material and legal effect of the cancellation of liabilities arises as a result of specific events that occurred in the course of court proceedings. The bankruptcy proceedings may be discontinued and, therefore, no debt relief may be granted.

The debt relief set out in the Act is inseparably connected with the public law element in the form of either a court decision on the cancellation of obligations or a court decision on the approval of the consumer arrangement. Theoretically, it is possible to cancel consumer debts completely under the contract or contracts concluded between the debtor and the creditor or creditors. In accordance with the Article 508 of the Civil Code, ${ }^{14}$ the obligation expires when the creditor releases the debtor from the debt and the debtor accepts the release. However, the "private" release of an insolvent debtor is in practice rare. The agreements come into effect and cause their legal consequences as a result of making declarations of will by all parties. Bilateral and multilateral agreements are distinguished in the general typology of contracts. As a rule, bilateral agreements have separate (usually antagonistic) interests for each party. To conclude a debt relief agreement, a consensus of all parties of the contract is essential. In the event of a debt relief by the bankruptcy court, the

\footnotetext{
${ }^{14}$ See Civil Code of 23rd April 1964, as amended.
} 
will of the creditors is irrelevant and in the case of a consumer arrangement, most creditors are sufficient for the debt relief. As a rule, the contract comes into effect solo consensus. It should be further pointed out that for the effectiveness of the contract it is not necessary to accept the authority of the state. Meanwhile, the arrangement - for its effectiveness - requires approval by the bankruptcy court. The effects of the agreement also apply to those creditors who voted against the arrangement.

A feature of the debt relief is its openness. In accordance with the Article $491^{14}$ Section 7 sentence 1 of the Act, a decision establishing a repayment plan for creditors or cancelling the debtor's obligations without establishing a repayment plan for creditors or conditional cancellation of the debtor's obligations without establishing a repayment plan for creditors shall be announced. Publicity of the debt is served by examining cases at the court hearing (see e.g. Article $491^{14}$ Section 4 of the Act and Article $491^{20 a}$ of the Act).

A feature of the consumer debt relief is its instance control (it is a possibility to appeal against crucial court's decisions). In accordance with the Article $491^{14}$ Section 7 sentence 2 of the Act, on the court's decision regarding the determination of the repayment plan of the creditors or on the cancellation of the debtor's obligations without establishing the repayment plan of the creditors or on the conditional cancellation of the debtor's obligations without establishing the repayment plan of the creditors, there is a complaint, which is a devolutory measure. In turn, according to the Article $491^{17}$ Section 1 of the Act, from the decision of the court of second instance on determining the repayment plan of the creditors or on the cancellation of the debtor's obligations without establishing the repayment plan of the creditors or on the conditional cancellation of the debtor's obligations without determining the repayment plan of the creditors a participant in proceedings is entitled to a cassation appeal.

A feature of the consumer debt is its widespread availability for insolvent natural persons who do not run a commercial activity. In support of the 2019 novel of the Act, it was written that "the regulation proposed in paragraphs 2 and 3 of the Article $491^{15}$ aims to dispel doubts that, although the principle remains the full coverage in the repayment plan of the costs temporarily incurred by the State Treasury, it is also possible to pay them partially in the event of limited earning possibilities of the 
bankrupt. This should eliminate cases in which the inability to fully repay the costs of the State Treasury prompted the courts to end the bankruptcy proceedings without establishing a repayment plan." 15

Debt relief is possible for socially acceptable cases - according to the axiological assumption of the legislator. If the debt is offset on the basis of an arrangement, the consent of most creditors is needed. Pursuant to the principle of volenti non fit injuria (who wants has no harm), most creditors can accept the terms of the consumer agreement, regardless of the premises of payment morality. Similarly, in the case of the arrangement concluded under the Restructuring Law Act, ${ }^{16}$ the entrepreneur's payment morality is not analysed. If the debt is discharged pursuant to a bankruptcy court order, then - to put it simply - the debtor must meet the criteria of payment morality.

\section{Payment morality of the debtor, its legal importance and final conclusions}

The importance of payment morality should be associated with the institute of a debt relief. In the justification of the bill from December 5, 2008 - which very narrowly opened the possibility of the debt relief - it was pointed out that "legal regulation of consumer bankruptcy, in order to fulfil its functions and not to pose a threat to the creditors and the security of legal transactions, must comply with the following assumptions: 1.) the debt relief must be an exception, not a rule - the debtor may use this mode only in exceptional cases and only if it guarantees that the debt will be used for a new start in life and that it will not be recklessly indebted; 2.) the possibility of the debt relief is a privilege for the debtor". ${ }^{17}$

De lege lata the debt relief, despite significant liberalization of regulations through subsequent statutory changes, is not of an "open" nature. In other words, the bankruptcy court when deciding on the debt relief of the bankrupt (i.e. in the case of judicial cancellation of the bankrupt's defaulted obligations) should examine - to a large extent - the so-called payment morality of the bankrupt.

Should not use the institute of the debt relief in the form of judicial cancellation of liabilities such a debtor who is deliberately in debt and then unable to satisfy creditors. A completely open debt relief option un-

\footnotetext{
${ }^{15}$ See Print No. 3480 of the Sejm of the Republic of Poland of the $8^{\text {th }}$ Term.

${ }^{16}$ See Restructuring Law Act of 15th May 2015, as amended.

${ }^{17}$ See Print No. 831 of the Sejm of the Republic of Poland of the $6^{\text {th }}$ Term.
} 
der consumer bankruptcy could promote negative social attitudes. Limiting access to the debt relief should be justified. Excessive liberalization of regulations may have such negative effects as limiting the availability of bank loans and increasing their costs, increasing the market position of para-bank institutions granting loans with aggressive margins.

It has been argued in the literature that the line between consumer protection and giving privileges to consumers is difficult to grasp in legislation. ${ }^{18}$ Consumer law should equalize the chances of weaker participants in the market (consumers). Excessive consumer protection may cause the phenomenon of the so-called moral hazard, i.e. claim attitudes and a lack of responsibility for the decisions taken, which ultimately turns against the consumer. Consumer law is also not an instrument by which consumer social protection can be implemented. Rather, such protection should be implemented within the scope of social protection law, health protection, combating unemployment, family policy, etc.

The legislator in the current wording has twice referred to the issue of the debtor's payment morality.

Firstly, in accordance with the Article 4914a Section 1 of the Act, "The court shall issue a decision to refuse to set up a creditors' repayment plan or to cancel a bankrupt's liabilities without establishing a creditors' repayment plan or to conditionally write off bankrupt's liabilities without establishing a creditors' repayment plan if: 1.) the bankrupt has led to his/her insolvency or significantly increased its degree in a deliberate manner, in particular by squandering the constituent parts of the property and intentionally not settling the payable liabilities; 2.) within ten years before the date of filing the bankruptcy petition in relation to the bankrupt, bankruptcy proceedings were conducted in which all or part of his/her liabilities were written off - unless establishing a repayment plan for creditors or writing off liabilities of the bankrupt without setting a credit repayment plan or conditional cancellation of the debtor's obligations without setting a credit repayment plan is justified on grounds of equity or humanitarian considerations."

Secondly, according to the Article $491^{15}$ Section 1a of the Act which stipulates following: "If it is established that the bankrupt has led to his/her insolvency or significantly increased its severity intentionally or

${ }^{18}$ See Print No. 3480 of the Sejm of the Republic of Poland of the $8^{\text {th }}$ Term. 
through gross negligence, the creditors' repayment plan may not be set for less than thirty-six months or more than eighty-four months."

The following conclusions can be drawn from the list of debt relief modes with the structure of payment morality. First of all, payment morality conditions the admissibility of only certain modes of the debt relief. The debtor's payment morality has no legal significance in the event of a debt relief under the consumer arrangement. Secondly, payment morality as a condition of the debt relief is not absolute. Equity or humanitarian considerations might be reasons for allowing a person who does not meet the criteria of payment morality to receive the debt relief. Thirdly, payment morality affects the course of some debt relief modes.

The legislator - in relation to the previous regulation - did not give up the census of the debtor's payment morality, but postponed the stage of its examination from the bankruptcy decree phase to the moment when the court makes a decision on debt relief and significantly liberalized the threshold of payment morality.

In accordance with the Article 49114a Section 1 of the Act, the court issues a ruling refusing to set up a creditors' repayment plan or cancelling the debts' obligations without establishing a creditors' repayment plan or conditional decommissioning of the bankrupt's obligations without establishing a creditors' repayment plan in two cases.

Firstly, there is no morality payment if the bankrupt has intentionally led to his/her insolvency or significantly increased its degree in a deliberate manner, in particular by squandering parts of the property and deliberate failure to settle payable liabilities. In this case, the morality of payment is in the form of a deliberate failure to pay. In other words, the payment morality of the bankrupt excludes intentional fault with a direct intention to lead to insolvency. In the Polish civil law, the design of guilt refers to the French concept of guilt as a two-element structure, combining two elements: subjective and objective. In the science of law, relationships between them are differently defined. The objective element referred to as unlawfulness means that the perpetrator's behaviour is inconsistent with the law or the principles of social coexistence. This is an objective category of assessment. The perpetrator can be accused of this misbehaviour. The subjective element of guilt (sometimes referred to as guilt sensu stricto) is sometimes recognized in the sense given to it by psychological theory as a perpetrator's offensive attitude to an act when his/her awareness and the will of a specific behaviour are directed to- 
wards behaviour contrary to the legal order or the principle of social coexistence. At present, however, the understanding of guilt according to normative theory prevails. The guilt is expressed in the possibility of accusing the perpetrator of inappropriate behaviour. Therefore, the body applying the law (in this case, the bankruptcy court) will assess the perpetrator's mental attitude from the outside. It is based on comparing his/her behaviour with a certain type of conduct. Adopting the assessment in abstracto theoretically prevents situations that exist in the case of using the assessment in concreto, where the perpetrator's psyche, his/her awareness, individual properties, etc., are determined. Therefore, an adequate pattern of conduct, the way of making comparisons as well as the scope of application of the assessment in abstracto require determination. ${ }^{19}$

Secondly, there is no morality payment if, within ten years before the date of filing for bankruptcy in relation to the bankrupt, insolvency proceedings were conducted in which all or part of his/her obligations were discontinued. In this case, the payment morality is in the form of no repeat default.

It should be reiterated that the premise of payment morality in the form of the lack of intentional insolvency and the lack of recidivism of insolvency applies only to certain modes of the debt relief. It applies to those procedures in which the court makes a substantive decision on the cancellation of the bankrupt's defaulted obligations. In turn, the payment morality of the debtor in this form is irrelevant for those modes of debt relief in which the debtor's liabilities are written off under the consumer arrangement adopted by most creditors.

The above-mentioned premises are not absolute. The court does not apply them if the establishment of the creditors' repayment plan or the cancellation of the debtor's obligations without establishing the creditors' repayment plan or the conditional cancellation of the debtor's obligations without establishing the creditors' repayment plan is justified by equitable or humanitarian considerations.

The normative juncture "or" indicates that the legislator used the ordinary alternative. The terms 'equity' and 'humanitarian considerations' may cross each other.

${ }^{19}$ See ADAMUS, R. Importance of Payment Morality in the Polish Bankruptcy Law. Journal of Business Law and Ethics [online]. 2019, vol. 7, no. 1-2, pp. 9-15 [cit. 2019-11-04]. ISSN 2372-4870. Available at: https://doi.org/10.15640/jble.v7n1_2a2. 
Scopes of the provisions of the Article 49114a Section 1 of the Act and the Article $491^{15}$ Section 1a of the Act intersect. The first of them mentions that "the bankrupt has led to his/her insolvency or significantly increased its degree in a deliberate manner, in particular by squandering the constituent parts of the property and intentional non-payment of due obligations". The second one mentions that "the bankrupt has led to his/her insolvency or significantly increased its degree intentionally or through gross negligence." However, the premise of the Article 49114a Section 1 of the Act is not absolute. This means that there may be an admissibility of the debt relief if it is justified by equity or humanitarian reasons. In this case, however, Article $491^{15}$ Section 1a of the Act imposes a longer repayment period.

If, in the absence of payment morality, there is no debt relief but bankruptcy funds have been accumulated in the bankruptcy proceedings, the court issues a decision establishing a repayment plan for creditors in which it lists the creditors participating in the repayment plan and divides the funds of the estate of bankruptcy between creditors participating in the repayment plan (Article $491^{14 a}$ Section 2 of the Act).

\section{References}

ADAMUS, R. Bank wobec upadłości konsumenckiej swojego dłużnika. Monitor Prawa Bankowego. 2011, vol. 2, nr 2, pp.53-70. ISSN 20819021.

ADAMUS, R. Bankruptcy and Restructuring Law in Poland. Societas et iurisprudentia [online]. 2019, vol. 7, no. 2, pp. 19-49 [cit. 2019-11-04]. ISSN 1339-5467. Available at: http://sei.iuridica.truni.sk/archive/ 2019/02/SEI-2019-02-Studies-Adamus-Rafal.pdf.

ADAMUS, R. Consumer Bankruptcy in Poland. International and Comparative Law Review [online]. 2011, vol. 11, no. 2, pp. 93-107 [cit. 201911-04]. ISSN 2464-6601. Available at: https://doi.org/10.1515/iclr2016-0106.

ADAMUS, R. Importance of Payment Morality in the Polish Bankruptcy Law. Journal of Business Law and Ethics [online]. 2019, vol. 7, no. 1-2, pp. 9-15 [cit. 2019-11-04]. ISSN 2372-4870. Available at: https://doi. org/10.15640/jble.v7n1_2a2.

ADAMUS, R. Likwidacja masy upadłości: Zagadnienia praktyczne. 1. wyd. Warszawa: Difin, 2014. 170 p. ISBN 978-83-7930-261-1. 
ADAMUS, R. Nowa upadłość konsumencka. Monitor Prawa Bankowego. 2015, vol. 6, nr 2, pp. 102-111. ISSN 2081-9021.

ADAMUS, R. Nowa upadłość konsumencka: Poradnik praktyczny. 1. wyd. Warszawa: Difin, 2015. 188 p. ISBN 978-83-7930-614-5.

ADAMUS, R. Upadłość osoby fizycznej nieprowadzącej działalności gospodarczej. Radca.pl. 2015, vol. 2, nr 2, pp. 25-34. ISSN 2543-7437.

ADAMUS, R. Wierzytelności banku w upadłości konsumenckiej. Jurysta. 2009, nr 3-4, pp. 41-45. ISSN 1230-7114.

ADAMUS, R. Zarys historii źródeł prawa upadłościowego w Polsce. Jurysta. 2009, nr 7, pp. 25-30. ISSN 1230-7114.

ADAMUS, R. Zaspokojenie wierzyciela rzeczowego w upadłości konsumenckiej. Przegląd Prawa Handlowego. 2015, nr 2, pp.33-37. ISSN 1230-2996.

ADAMUS, R., A. J. WITOSZ and A. WITOSZ. Upadłość konsumencka: Komentarz praktyczny. 1. wyd. Warszawa: LexisNexis, 2009. 102 p. ISBN 978-83-7620-118-4.

ALTMAN, D. Prawo upadłościowe: Komentarz. 1. wyd. Warszawa: Księgarnia Powszechna, 1936. 442 p.

BABIARZ-MIKULSKA, K. Postępowanie upadłościowe wobec osób nieprowadzących działalności gospodarczej. Przegląd Prawa Handlowego. 2011, nr 12, pp. 55-58. ISSN 1230-2996.

Bankruptcy and Reorganization Law Act of $28^{\text {th }}$ February 2003, as amended.

BUNK, A., V. LICHTER and M. R. PIETRZAK. Upadłość konsumencka w Niemczech. Fenix.pl. 2011, vol. 2, nr 4, pp. 29-34. ISSN 2082-3398.

CAŁUS, E. Upadłość konsumencka - doświadczenia i perspektywy. Przegląd Prawa i Administracji. 2015, nr 101, pp. 11-24. ISSN 0137-1134.

CHAJDA, M. and M. SKWARZYŃSKI. Upadłość konsumencka twórcy. In: M. ZAŁUCKI, ed. Własność intelektualna w prawie upadłościowym i naprawczym. 1. wyd. Warszawa: IUSatTAX, 2012, pp. 43-53. ISBN 97883-62682-12-6.

Civil Code of 23 ${ }^{\text {rd }}$ April 1964, as amended.

FALKIEWICZ, K. and K. DOPIERAŁA. Wady ustawy o upadłości konsumenckiej. Fenix.pl. 2013, vol. 4, nr 2, pp. 22-26. ISSN 2082-3398. 
FILIPIAK, P., A. HRYCAJ and Ł. LIPOWICZ. Upadłość konsumencka po dużej nowelizacji: Komentarz. 1. wyd. Poznań: Spartian, 2015. 326 p. ISBN 978-83-64651-13-7.

GEROMIN, M. Upadłość konsumencka w świetle zmian wprowadzonych ustawą - Prawo restrukturyzacyjne. Monitor Prawniczy. 2016, vol. 24, nr 4, pp. 177-187. ISSN 1230-6509.

GŁODOWSKI, W. and A. HRYCAJ. Postępowanie w przedmiocie ogłoszenia upadłości konsumenckiej. Ruch Prawniczy, Ekonomiczny i Socjologiczny. 2011, vol. 73, nr 3, pp. 113-123. ISSN 0035-9629.

GŁODOWSKI, W. and A. HRYCAJ. Zakres podmiotowy i podstawy ogłoszenia „upadłości konsumenckiej”. Państwo i Prawo. 2010, vol.65, nr 2, pp. 70-82. ISSN 0031-0980.

GURGUL, S. Postępowanie upadłościowe wobec osób fizycznych nieprowadzących działalności gospodarczej: Część 1. Monitor Prawniczy. 2009, vol. 17, nr 10, pp. 527-537. ISSN 1230-6509.

GURGUL, S. Postępowanie upadłościowe wobec osób fizycznych nieprowadzących działalności gospodarczej: Część 2. Monitor Prawniczy. 2009, vol. 17, nr 11, pp. 592-601. ISSN 1230-6509.

HANSHEW, M. Upadłość konsumencka w Niemczech. In: R. BALICKI, ed. Pro Publico Bono: Zeszyt 1. 1. wyd. Wrocław: Wydawnictwo Uniwersytetu Wrocławskiego, 2005, pp. 129-139. ISBN 978-83-229-2678-9.

HOFMAN, T. Upadłość konsumencka 2015. Monitor Prawniczy. 2015, vol. 23, nr 16, pp. 858-863. ISSN 1230-6509.

HRYCAJ, A., A. OWCZAREWICZ and A. PAWŁOWSKI. Postanowienie sądu o ustaleniu planu spłaty w postępowaniu upadłościowym prowadzonym wobec osoby fizycznej nieprowadzącej działalności gospodarczej. Doradca Restrukturyzacyjny. 2016, nr 4, p. 32. ISSN 2450-1956.

JANDA, P. Czynności syndyka w postępowaniu upadłościowym prowadzonym wobec osób fizycznych nieprowadzących działalności gospodarczej w ujęciu praktycznym. Doradca Restrukturyzacyjny. 2016, nr 1, pp. 23-31. ISSN 2450-1956.

JAŚLIKOWSKI, M. Podstawy ogłoszenia upadłości konsumenckiej w praktyce sądów powszechnych. Prawo w Działaniu [online]. 2011, nr 10, pp. 43-99 [cit. 2019-11-04]. ISSN 2657-4691. Available at: https:// iws.gov.pl/wp-content/uploads/2018/09/Marek-Ja\%C5\%9Blikow- 
ski-Podstawy-og\%C5\%82oszenia-upad\%C5\%82o\%C5\%9Bci-konsumenckiej-w-praktyce-s\%C4\%85d\%C3\%B3w-powszechnych-43.pdf.

KABZA, E. Upadłość konsumencka w USA. Przegląd Prawa Egzekucyjnego. 2010, nr 5, pp. 79-110. ISSN 1731-030X.

KABZA, E. Wybrane problemy upadłości konsumenckiej w świetle nowej regulacji. Studia Iuridica Toruniensia [online]. 2009, nr 5, pp. 121139 [cit. 2019-11-04]. ISSN 2391-7873. Available at: https://doi.org/ 10.12775/sit.2009.007.

KUGLARZ, P. Podstawowe standardy upadłości konsumenckiej w Polsce na tle wybranych regulacji europejskich. Doradca Restrukturyzacyjny. 2015, nr 1, pp. 33-43. ISSN 2450-1956.

LEWANDOWSKI, R., G. TARKOTTA and P. WOŁOWSKI. Projekt ustawy o przeciwdziałaniu niewypłacalności oraz o upadłości osoby fizycznej na tle niemieckiej regulacji upadłości konsumenckiej - uwagi de lege lata i de lege ferenda. Rejent. 2008, vol. 18, nr 1, pp. 99-116. ISSN 1230-669X.

MEDYŃSKI, M. and K. FORYSIAK. Status wierzyciela w postępowaniu upadłościowym osoby fizycznej nieprowadzącej działalności gospodarczej. Monitor Prawa Bankowego. 2016, vol. 7, nr 6, pp. 88-100. ISSN 2081-9021.

MEDYŃSKI, M. and K. KRAWIEC. Małżeńskie ustroje majątkowe w przypadku ogłoszenia upadłości konsumenckiej. Monitor Prawa Bankowego. 2016, vol. 7, nr 5, pp. 83-92. ISSN 2081-9021.

MICHALAK, K. Ogłoszenie upadłości osób fizycznych nieprowadzących działalności gospodarczej na podstawie znowelizowanej ustawy Prawo upadłościowe i naprawcze. Transformacje Prawa Prywatnego. 2009, nr 3-4, pp. 67-88. ISSN 1641-1609.

MICHALAK, K. Przebieg konsumenckiego postępowania niewypłacalnościowego (surendettement personel) i postępowania prowadzącego do uwolnienia osoby fizycznej z reszty długów (retablissement personel) we Francji. Transformacje Prawa Prywatnego. 2008, nr 2, pp. 49-75. ISSN 1641-1609.

MICHALAK, K. Przesłanki wszczęcia konsumenckiego postępowania niewypłacalnościowego (surendettement personel) i postępowania prowadzącego do uwolnienia z reszty długów (retablissement personel) 
we Francji. Transformacje Prawa Prywatnego. 2008, nr 1, pp. 33-56. ISSN 1641-1609.

NAMITKIEWICZ, J. Podręcznik prawa handlowego, wekslowego, czekowego i upadłościowego. 3. wyd. Warszawa: F. Hoesick, 1927. 574 p.

PANNERT, M. Upadłość konsumencka po zmianach - problemy węzłowe. In: J. OLSZEWSKI, ed. Tendencje reformatorskie w prawie handlowym: między teoriq a praktyką. 1. wyd. Warszawa: C. H. Beck, 2015, pp. 135-143. ISBN 978-83-255-7784-1.

Print No. 3480 of the Sejm of the Republic of Poland of the $8^{\text {th }}$ Term.

Print No. 556 of the Sejm of the Republic of Poland of the $6^{\text {th }}$ Term.

Print No. 831 of the Sejm of the Republic of Poland of the $6^{\text {th }}$ Term.

Restructuring Law Act of 15 th May 2015, as amended.

RUTKOWSKA, M. Upadłość konsumencka - przegląd regulacji wybranych systemów prawnych. Bank i Kredyt. 2004, vol. 35, nr 11-12, pp. 5873. ISSN 0137-5520.

SAGAN, B. Zmiany w regulacji upadłości konsumenckiej - wybrane zagadnienia. In: J. OLSZEWSKI, ed. Tendencje reformatorskie $w$ prawie handlowym: między teoriq a praktykq. 1. wyd. Warszawa: C. H. Beck, 2015, pp. 145-152. ISBN 978-83-255-7784-1.

SIEDLECKI, W. Międzynarodowe prawo upadłościowe. Przegląd Prawa i Administracji. 1937, nr 62, p. 7. ISSN 0137-1134.

SOKAL, P. Postępowanie upadłościowe wobec osób fizycznych nieprowadzących działalności gospodarczej. Przegląd Prawa Egzekucyjnego. 2009, nr 8, pp. 79-111. ISSN 1731-030X.

ŚWIECKA, B. ed. Bankructwa gospodarstw domowych: Perspektywa ekonomiczna i społeczna. 1. wyd. Warszawa: Difin, 2008. 320 p. ISBN 978-83-7251-918-4.

SZAFRAŃSKI, P. Uwagi do projektu zmian w prawie upadłościowym osób fizycznych nieprowadzących działalności gospodarczej, przedstawionego na konferencji Ministerstwa Sprawiedliwości oraz Ministerstwa Gospodarki w dniu 10 grudnia 2012 roku. Polski Proces Cywilny. 2013, nr 2, pp. 174-193. ISSN 2082-1743. 
SZPRINGER, W. Kredyt konsumencki i upadłość konsumencka na rynku usług finansowych UE. 1. wyd. Warszawa: Dom Wydawniczy ABC, 2005. 253 p. ISBN 83-7416-235-X.

SZPRINGER, W. Społeczna odpowiedzialność banków: Między ochronq konsumenta a osłonq socjalna. 1. wyd. Warszawa: Wolters Kluwer, 2009. 309 p. ISBN 978-83-7601-763-1.

SZPRINGER, W. Upadłość konsumencka: Inspiracje z rozwiq̨zań światowych oraz rekomendacje dla Polski. 1. wyd. Warszawa: CeDeWu, 2006. 85 p. ISBN 978-83-60089-25-5.

TATARA, K. and M. KALIŃSKI. Wątpliwości odnośnie do przesłanki złożenia wniosku o ogłoszenie upadłości w terminie w przypadku menedżerów lub byłych przedsiębiorców ubiegających się o upadłość konsumencką. Doradca Restrukturyzacyjny. 2015, nr 1, pp.81-87. ISSN 2450-1956.

TERESZKIEWICZ, P. Postępowania upadłosciowe i oddłużeniowe dla konsumentów w Stanach Zjednoczonych i w niektórych krajach europejskich: Część 1. Transformacje Prawa Prywatnego. 2000, nr 1-2, pp. 99-122. ISSN 1641-1609.

TERESZKIEWICZ, P. Postępowania upadłościowe i oddłużeniowe dla konsumentów w Stanach Zjednoczonych i w niektórych krajach europejskich: Część 2. Transformacje Prawa Prywatnego. 2000, nr 3, pp. 27-57. ISSN 1641-1609.

WERENGOWSKI, J. Postępowanie upadłościowe bez udziału wierzycieli. Doradca Restrukturyzacyjny. 2015, nr 1, pp. 44-50. ISSN 2450-1956.

WITOSZ, A. J. Likwidacja własna masy upadłości przez konsumenta. Monitor Prawniczy. 2009, vol.17, nr 19, pp.1074-1080. ISSN 12306509.

WITOSZ, A. J. Plan spłaty wierzycieli w upadłości konsumenckiej. Monitor Prawniczy. 2010, vol. 18, nr 10, pp. 584-592. ISSN 1230-6509.

WITOSZ, A. J. Przesłanki ogłoszenia upadłości konsumenckiej. Przegląd Prawa Handlowego. 2015, nr 2, pp. 24-32. ISSN 1230-2996.

WITOSZ, A. J. Skutki prawne upadłości wspólnika spółki osobowej. Przegląd Prawa Handlowego. 2014, nr 4, pp. 8-12. ISSN 1230-2996.

WITOSZ, A. J. Wierzyciel w upadłości konsumenckiej. In: J. OLSZEWSKI, ed. Tendencje reformatorskie w prawie handlowym: między teoriq 
a praktykq. 1. wyd. Warszawa: C. H. Beck, 2015, pp. 113-124. ISBN 978-83-255-7784-1.

WITOSZ, A. Przekształcenie jednoosobowego przedsiębiorcy w jednoosobową spółkę kapitałową a problem zdolności upadłościowej. Przegląd Prawa Handlowego. 2013, nr 4, pp. 4-7. ISSN 1230-2996.

WITOSZ, A. Układ w upadłości konsumenckiej. Przegląd Prawa Handlowego. 2015, nr 2, pp. 18-23. ISSN 1230-2996.

WOŁOWSKI, P. Układ w upadłości konsumenckiej - wybrane zagadnienia. Rejent. 2015, vol. 25, nr 8, pp. 121-137. ISSN 1230-669X.

WOŁOWSKI, P. Upadłość konsumencka na podstawie nowelizacji ustawy Prawo upadłościowe i naprawcze z dnia 29 sierpnia $2014 \mathrm{r}$. Transformacje Prawa Prywatnego. 2014, nr 4, pp. 53-68. ISSN 1641-1609.

ZACHMIELEWSKA, O. Upadłość konsumencka w świetle domniemania racjonalności ustawodawcy. Państwo i Prawo. 2010, vol.65, nr 11, pp. 96-107. ISSN 0031-0980.

ZALEWSKI, C. Nowelizacja prawa upadłościowego i naprawczego. Przegląd Prawa Handlowego. 2009, nr 5, pp. 4-7. ISSN 1230-2996.

ZIMMERMAN, P. Prawo upadłościowe i naprawcze: Komentarz. 2. wyd. Warszawa: C. H. Beck, 2012. 1084 p. ISBN 978-83-255-3091-4.

ZIMMERMAN, P. Prawo upadłościowe i naprawcze: Komentarz. 3. wyd. Warszawa: C. H. Beck, 2015. 1232 p. ISBN 978-83-255-6878-8.

Prof. UO dr hab. Rafał Adamus Faculty of Law and Administration University of Opole Katowicka 87a 45-060 Opole Poland radamus@uni.opole.pl 